\section{International Scientific Journal Theoretical \& Applied Science}

Ulugbek Toshmurotovich Yazdanov

Senior Researcher Degree-seeking student Samarkand State University named after Alisher Navoi,

p-ISSN: 2308-4944 (print) e-ISSN: 2409-0085 (online) yaz-81@rambler.ru

Year: $2015 \quad$ Issue: 09 Volume: 29

Published: $30.09 .2015 \quad$ http://T-Science.org

SECTION 30. Philosophy.

\title{
GLOBAL PROBLEMS: HISTORICAL FORECASTING AND NECESSITY OF DEVELOPING OF THE PUBLIC OPINION
}

\author{
Abstract: On basis of historical analyses in this article discovered threats that getting to human evolution and \\ nature stability that happening from genesis the forming global problem and happening among escalating process \\ of functional integration. Also offered planned way and recommendation on human habitation and achieving \\ consistent development of nature. \\ Key words: public opinion, global problems: demographic explosion, provision, power industry, production, \\ deficit of water, ecological crisis, clash of Civilizations, functional integration. \\ Language: English \\ Citation: Yazdanov UT (2015) GLOBAL PROBLEMS: HISTORICAL FORECASTING AND NECESSITY \\ OF DEVELOPING OF THE PUBLIC OPINION. ISJ Theoretical \& Applied Science 09 (29): 76-82. \\ Soi: http://s-o-i.org/1.1/TAS-09-29-17 Doi: crossef http://dx.doi.org/10.15863/TAS.2015.09.29.17
}

The reality of $21^{\text {st }}$ century is relations between opinions, doctrines, concepts of people, nations, states and humanity on life, are very complicated, even it is conflicting in some cases. That's why nowadays we can feel the urgent necessity for developing matter of public opinion on Global problems, and the urgent necessity for scientific research. Because by developing the public opinion it is possible to provide all the people living on the Earth with comfortable and secure life. On this matter scientific research in large scale has begun in western countries since $80 \mathrm{~s}$ of last century. But current problems do not still lose their importance.

\section{Marks of the problem:}

Nowadays it is clear that global problems and forecasting tendencies which aimed to solve these problems are in the centre of the public opinion. Because new increasing natural and artificial problems leading to the unsafe place to live, makes humanity to worry about. Today as a result of high developing of world science and technology, natural resources are used more as ever in everyday usage. Besides these, increasing the population of the world year by year requires to produce much food, oil, clothes and others as well. All these cause decreasing the area of forests, spreading the wide deserts, spoiling the ground, widening the holes of ozone layer above the atmosphere, rising the average temperature of the Earth and est [1, 100].
We know that the health of human being is the supreme. Today, one of the factors that could cause serious harm to human health is a problem related with water. So that, we can say that Water War is possible in $21^{\text {st }}$ century. Because in the lecture of 'Global Water Security published in 2012, American analysts mentioned that for the next 10 years 'Water instability in the world' will appear and water sources can become an instrument of pressure. On this issue Hillary Clinton, a former State Secretary of the USA said that the population of the world is growing. Thus, the demand for water increases, and appearing problems, of course, increases the risk of instability between countries and within countries, too. There are some reasons to cause regional instability related with water in the near future, and those reasons are followings: 97.5 percent of all the water reserves in the Earth is salt water; fresh water available for human life is only 2.5 percent. If we take into account that their 75 percent is mountain and polar ices, 24 percent is subsoil waters, 0.5 percent is moisture in the soil, easy to use and the most inexpensive fresh water is in the lakes, rivers, underground water and other water sources. They made up 0.01 percent of total water resources of the world.

According to the statistics 3.8 thousand cubic water have been used by people every day, according to the calculations of scientists, fresh water reserves will seriously decline next $25-30$ years. To be more 
precise, fresh water reserves will be used up by 2100 , all fresh water reserves of the Planet will end completely by 2230 [2, 148]. Because according to the latest estimates, nowadays 70 percent of the fresh water consumed in agriculture, 20 percent in industrial production, $10 \%$ in domestic consumption. In the beginning of $21^{\text {st }}$ century the need for clean drinking water around the world is increased 2-3, 2-5 [3] times than 1990's. If the need for drinking water increases in this way, 90 percent of drinking water reserves will be expected to allocate in agriculture by 2050 . As you know, some countries have already finished their water resources. Sadly, by appearing problem not only nature, but the man being has also been suffering most. For example, according to the data of UN Environmental Protection Program, half of the world's rivers are seriously polluted now. 40 percent population of the Earth is suffering from a lack of clean drinking water. Because of the lack of clean drinking water 1.2 million people will be exposed to a variety of diseases every year, 5 million people are drinking the water with poor quality and polluted water.

World statistical data shows that by the years 2020-2025, all fresh water resources will be taken for human activity, and fresh water can be the source of investment, and it is likely to be sold. If we take into account that during the last 100 years around the World water consumption had an increase of six times, by 2050 people will need for two times much water than nowadays. Unfortunately, the water sources are decreasing rapidly. Now 1.1 billion people around the World are constantly struggling with water shortages. More than 2 billion people are faced with this problem from time to time. This figure represents almost half of the population of the Planet have fresh water scarcity risks. The most worrying aspect is that, every day, 6,000 people (mostly children) die due to this problem or its consequences. It is forecasting that 500 million people may migrate to other continents looking for fresh water by 2030 .

One of the universal problems which has been required to meet human needs constantly is a problem of food. Today we know that, providing very fast-growing world population with food in many regions of the world in recent years is not good. For example, due to malnutrition nearly 11 million children under the age of 5 pass away every year in the world [2, 203]. As a result of measures to mitigate this situation, the development of reserves growth, on the one hand, widening the agricultural land, on the other hand, increasing the productivity of arable land, has been provided by. In the recent years, many activities have been carried out to increase the productivity, including it was reached that the risk of the food crisis has been decreased by increasing the global harvest productivity till 90 percent in 1980s [3]. However, to achieve such success might cause to destruct any natural balance. Because as a result of solving the food crisis, a lot of land was degraded, in other words, the natural environment is being destroyed by the pressure of man. The most dangerous aspect of the problem is there is no any opportunity to return to the land's natural position. Such a dangerous situation came out because of the followings; first of all, the natural growth process developed at a very fast pace; secondly, to meet their needs for jobs and food products. In fact, Thomas Robert Malthus, the English economist forecasted about the origin of this problem in $18^{\text {th }}$ century. In his book 'An Essay on the Principle of Population' he wrote that if we did not prevent the increase in the population by geometric profession, in the near future in the planetary scale, the natural environment, which may be material with a good amount of conflict between the needs of the rapidly growing world population may occur [4]. Malthus' predictions are reflecting in full power in practice.

Today, the environmental situation is counted one of the global problems which depends on the health of man. Because a violation of the ecological balance is not only current problem of man, but the problem is directly related to the future of the planet, too. One example, according to the UN data, 80-85 billion tons of fuel combustion id used on the planet in the history of man till now. The half of that amount is used last 25 years. 2 billion tons of coal is burned per year [5, 207]. At present, 15 billion tons of gas and dust is adding to the atmosphere in the result of burning a variety of fuels, including natural gas, combustible shale, peat, wood, forest fire, the volcanic eruption. According to the academic A.P.Vinogradov, in 2200 the amount of carbon dioxide in the atmosphere will be increased to 20 percent comparing today. Before the start of the revolution in science and technology the amount of carbon dioxide in the atmosphere was in balance for a long time. Because by photosynthesis plants have been processing 110 billion tons, or 5 percent carbon dioxide in the atmosphere. If the Atmospheric pollution increases in this rate, what consequences the mankind will face with in the future? It is natural that such questions will make any person to think about seriously. Because the changes in the atmosphere produces a range of global issues for humanity. In particular, average temperature of the World rose by $0.74^{\circ} \mathrm{C}$ over the last 100 years. Experts on climate change are warning that the global ocean levels may rise 20-50 centimeters as a result of active melting of the glaciers in Antarctica and Greenland until 2100, and it cause the flood in the many island states and coastal cities. Because according to the report 'Climate Change 2007' prepared by the Intergovernmental Commission of $\mathrm{UN}$, the temperature of the Earth may increase from 1.4 to $3.8^{\circ} \mathrm{C}$ the next 100 years. [6, 3] Besides 
these, today one of the worrying situations is that the ozone layer, which protects the Earth from harmful gases, has been removing as a result of the increase of gas emissions to the atmosphere. In other words, the part of atmosphere located at an altitude of 15-25 $\mathrm{km}$ above the Earth level is called as an ozone layer, it is known as the ozone screen, too.

The ozone layer receives ultraviolet rays from the sun, and protects all living organisms on the Earth from the harmful effects of ultraviolet rays. There are many factors to deplete the ozone layer, but a self-restoration process of nature prevents the ozone layer over from its gradual depletion. Natural equilibrium is being destroyed by the aggression of man. The most worrying aspect of it is that the opportunities created by the human hand produce the instability in the nature; on the other hand, it leads man to fall into a decline. There are some bases for those thoughts. For example, some industrial networks receive a large amount of oxygen from the atmosphere, while they produce different gases and substances. To produce a ton of iron from ore $150 \mathrm{~m}^{3}$ oxygen, a ton of steel $35-70 \mathrm{~m}^{3}$ oxygen, and a ton of ammonia $500 \mathrm{~m}^{3}$ oxygen and a ton of acetylene 3600 $\mathrm{m}^{3}$ oxygen is used. In recent years the demand for oxygen to get steel increased 2.6 times and in blast furnaces it increased by 4.2 times. In general, the oxygen is being used five times more in industry last five years. Which is more important for mankind 'wealth' or 'life'? Another example, according to the data, $70-80$ percent air pollution is because of vehicles. Y.V.Novikov said that automobiles pollute the air by producing more than 200 different aerosol particles. Each car $200 \mathrm{~kg}$ (mainly gasoline) and 300 $\mathrm{kg}$ of air is used. By consumption that fuel a car produces $700 \mathrm{~kg}$ of carbon dioxide, $230 \mathrm{~kg}$ of carbohydrates, $30 \mathrm{~kg}$ of nitrogen oxide and $2-5 \mathrm{~kg}$ of solid substances into the air [7, 121].

In conclusion, man is leading the Planet on which he lives himself to the catastrophe, and he is doing it consciously. Because human can live with poor suffering health for years, without foot for months, without drinks it is available for a week. If there is no any oxygen for breathing, man will not be able to live even for a moment. And man still does not want to understand that.

For example, nowadays the USA is not only one of the leading industrial countries of the world, but it is one of the leading countries using oxygen much more than other countries, too. All plants in the USA are not able to provide such amount of oxygen that is used by industry, transportation, population and the fauna in the country. That's why, today the USA lives at the expense of clean air of other countries.

On the one hand man makes problems connected with food, water and oxygen to survive, but on the other hand, man makes the Earth unsuitable to live on. But we are responsible to supply the future generations with pure nature. It may cause not only person's self-destruction, but it may lead mankind to extinction as the descendants of the dinosaurs, too. For example, today thousands of hectares of grounds have been used for the expansion of cities; the construction of industrial enterprises. So many forests are being cut off, and green land is decreasing. This trend is very dangerous, especially in developing countries. About 0.8 percent of tropical forests are disappearing each year, 200 thousand $\mathrm{km} 2$ tropical forests are cut, and it is renewable. Currently 8.3 million hectares or 16 hectares of forest is being cut per year [3]. In a word, winner over the nature is not man, but the technology created by man. We should not forget that the technology needs mankind to create the existence of the future generation. In addition, for the last 25 years 45 percent of coal, 57 percent of iron ore, 76 percent of oil, 80 percent of natural gas is produced from the beginning of the twentieth century to the present day. This figure can be observed in other types of raw materials. For example, in 1990s the production of raw materials' amount increased 1.5-2 times comparing to the 1960$70 \mathrm{~s}$, and now it has increased 2.2 times [3]. Appearing of that situation can cause the tension in raw-material resources which are important for mankind; and have resulted in a reduction of fertile land and drinking water sources. One more important point is that the environmental situation and a violation of the natural environment will affect to the human body and his activities of production.

As one of the factors which have been leading to the destruction of mankind, we can show the decline in energy and fuel resources. Because need for energy of the industry and national economy has deteriorated as a result of increasing energy consumption. We know that energy determines the pace of development of the world economy. According to data, in the next few years the demand for energy and fuel resources will be 20 billion tons; by 2025 it will be $35-40$ billion. By the end of $21^{\text {st }}$ century it will be $80-85$ billion tons. This process shows that a serious conflict between man and natural resources in recent years is possible. It should be emphasized that the natural resources, which are used for their own needs, are not infinite. In other words, if the development of man and nature is not functionally integrated, man will face with the most significant and irreversible damage. As Professor Sayd Mamashokirov said, the current generation's fortune gained by harming the ecology of biosphere is the beginning of misfortune for future generations.

Misunderstood aspect of the human race is that man leads himself and his future towards the destruction, on the one hand, man is trying to continue reproduction. In fact, all of the abovementioned problems are directly related to demographic changes. Historically, we know that the concept of 'Demographic bang' is reflected since $20^{\text {th }}$ 
century. The notion of 'Demographic bang' means a rapid increase of the birth rate amount in the short period of social and historical development in a particular region or country, and also, the population of the Earth is growing very fast. By occurring this process, food shortages, water scarcity, environmental pollution, and the renewable balance of nature, environmental crises and other problems are developing today. As information, according to some experts, the energy, raw materials, food and other resources in the Planet are enough only for one billion people to live a decent life. It means that the population of the USA, Europe and Japan is equal to that amount. For this reason, some analysts are trying to name these countries as 'The golden billion'. These countries use more than half of the energy and 70 percent of the metals. And the most important point is that they produce 75 percent of the waste. Particularly, the US uses 40 percent of the world's natural resources, and 60 percent of pollution has been made in this country.

According to the specialists, if other countries also use the natural resources as the US does, probably world's oil reserves will end in 7 years, natural gas in 5 years, coal in 18 years. The worrying aspect of the problem is that the process of 'Demographic bang' is increasing, while the world's natural reserves are declining. For example, at the beginning of $20^{\text {th }}$ century 1.5 billion people lived on the Earth, in 1950 population grew 2.5 billion people in spite of the World War II, and it increased for 70100 million people every year. In 1993 it was 5.5 billion people, it shows that population has increased two times higher than in the middle of the last century. According to the UN data, On July 11, 1987 a five-billionth-baby was born. Sixth billion was in the year of 1998. At present time every year 130 million people are born, that the 50 million people die, thus the population has been increasing about 80 million people every year. About 6.5 billion people $[2,180]$ live on the Planet now. If the population growth continues in the same way, it will be 14 billion by $2050-2070$ [8, 20]. In a word, man is leading himself towards recession.

\section{Researches aimed to solve the problem:}

A mankind is counted as a driving mechanism of organizational, formational and developing stages of all above mentioned problems. So, today only man is unique solution for all problems of global importance, because of man there are so many problems. We should develop the public opinion that only man can defeat all these issues. That is very important. There are some international organizations which are responsible to identify the factors and of course the causes of the current and new problems; and these organizations try to develop the public opinion against these issues and try to focus on the international scale. For example, The Club of Rome is one of the organizations, which studies the causes of the global problems in scientific-theoretical and practical principles. The main function of this organization is that it aimed to guide the international community to solve the current global problem. In other words, developing the public opinion, which directed to eliminate the factors and the origin of the problems in the global importance, is the main objective of The Club of Rome. One of the main tasks of this prestigious international organization is to prepare and publish the most important reports on global human problems. 'The Limits to Growth', the first report of the organization, published in 1972, was the very popular. We should note that the number of all reports prepared by the Club of Rome is more than thirty today. In the preface of 'The Limits to Growth' the founder of the Club of Rome Aurelio Peccei said: Now none of the healthy minded person do not believe in that our Earth is not able to endure the growth rates and any erratic habits of mankind. It is obvious that Growth has its limits, but we need to identify where and how' [9, 123-124].

We know that the formation, development, and eventually eliminating of any problem is directly connected with the level of the development of public opinion. The Club of Rome understood this principle correctly, so it got great reputation in the first publication. The reports prepared by Jay Wright Forrester, Donella Meadows, Jan Tinbergen Alexander King and others, the members of the Club of Rome, have great scientific importance in developing the public opinion on serious scientific prophecies about the future prospects of civic society. In the reports serious considerations, in which written about terrible consequences of pressure and attack to the nature by man; and expanding the global problems which might be very dangerous for the future prospects, are written. The prophecies by the members of the Club of Rome were in scientific and philosophical nature, and in these prophecies we can see the important scientific conclusions about the future of mankind. And the conclusions were mainly based on the categories and the laws of logic; and practice on tested knowledge. In a word, in defining the future prospects of human development, the most important characters include understanding of the nature of the global problems. Man should understand that all these problems can be resolved by corporative development of the public opinion in the way of global interests.

As noted, the Club of Rome could attract the public attention with its first report published in 1972. Because the report of the organization was prepared by approaching the scientific researches of great scientists of the world. The Report was based on the project 'The Predicament of Mankind' created under the rule of Donella Meadows at the Technological institute of Massachusetts (USA). The Club of Rome tries to explain the most important 
parts of these problems by the following attributes. First of all, the formation of public opinion on that the future problems facing in the beginning of $21^{\text {st }}$ century are very complex and very important; secondly, creating the chances for survival of mankind, and the formation of new relationships aimed to prevent the possibility of the global disasters and est. The Club of Rome usually warns the human being about social consequences of economical, industrial, scientific-technical problems facing humanity in future, and by these the club aimed use the public opinion in solving the problems.

In 1991 the Club of Rome announced to the people of the world about the cooperation. The origin of the global problems of humanity, and issues on saving the mankind are widely analyzed in the report 'The First Global Revolution'. It was noted in the report that the international partner organizations should understand the seriousness of this issue, every person should be involved in this matter. 'We challenge for global cooperation', written in the report. In general, though as Donella Meadows and his colleagues stated 25 years ago: 'Humanity is moving towards the tragedy, it should be solved', these ideas have not lost their importance yet. It has already been global issue, and requires the formation of the wide public opinion which focuses on the real solution of problems.

Besides these, here we want to speak about the concept of academic N.Moiseyev, a famous Russian scientist, who has given special attention to the formation of public opinion focusing on solving global problems. The crisis of modern civilization and the ways out of the crisis are described in detail in Moiseyev's prospectus 'The Destiny of Civilization'. Moiseyev warned the humanity about that was the Planet was near to the unknown and the inevitable destruction ...; according to his ideas this destruction would be expected in not unknown future, but it might occur in the middle of $21 \mathrm{st}$ century, and he challenged the humanity for awareness and cooperation. In his opinion, there is only way to prevent this destruction, it is very necessary that everybody should feel himself as a part of nature; and the people of the world should know that the planet is the only home to live in; they should begin to live on the basis of civilization paradigm and moral principles. Зарурдир [10, 5-6]. By studying the thoughts of scientists we can understand a truth that it will be impossible to save the Planet, if we do not develop the corporative cooperation in the public opinion aimed at solving the problems that arose.

The Moiseyev group, which stated the formation of public opinion focused on solving the global issues, counted that economic, technical, technological, and intellectual support is very important in the solution of global problems on spiritual security. That's why, it is impossible to solve the problems on social, spiritual security for countries separately, and the group is looking for the alternative way of development for humanity. According to the group members the conflicts of civilizations could be solved evolutionary as a result of creating an effective management of integration, cooperation, corporate interests, in other words, an effective control of public opinion. Moiseyev described that evolutionary process in the following. Today socio-political development practices of human being can prove that it led the society into a synergetic and complicated way. Billions of people on Earth is getting understand it time by time, and mankind is trying to change the development paradigm, and they are near to the evolutionary way of development. It is earth on face of resident milliardth men gradually to catch and humanity changing progress of paradigm, evolution development on a way expiration costs ahead [11, 48]. His ideas on possible zones of conflicts between civilizations have very critical importance.

Moiseyev wrote about the necessity of an important milestone in the history of mankind. And he said that humanity is on the threshold of the third major reconstruction. In his opinion, mankind should find not only a new wider ecological chain, but the process of anthropogenesis is to be restructured, too. Besides these, the contents of civilization, its objectives, the nature of bilateral relations, the relationship between the people should be changed. In order to get the implementation of this process, it requires following to the thought of the team, in other words, following to the public opinion is one of the most important and urgent tasks.

\section{Ways to solve the problem:}

The necessity of formation of the public opinion aimed to solve the problems of global importance can be explained by the following scientific-theoretical proposals:

First, civilization of society is an objective process that moving constantly. But the subjects, affecting the development of evolution in the way of their interests, destroy the natural gradualness, and the opportunity to restore them-selves has been deprived. The most worrying point of the problem is that the number second, third and other new problems are growing while current problem has not solved yet. The reasons to appear this situation could be related to different factors. For example, the wellknown scientists and philosophers like Herbert Marcuse, Theodore Roszak, P.Goodman and other accused their predecessors on cruel scientism, accused them on trying to make man a slave of science and technology. And they opposed to the development of science and technology. As a result, a new wave of protest against the development of science, technology and social progress, appeared. Appearing ideas under the wave tried to prove anticonsumer society, and tried to persuade man to be 
patient with little content. They believe in that modern technologies were the main perpetrator in the process of trying to find a guilty on appearing the global problems. They had suspected not only in science, but the idea of progress. At that time JeanJacques Rousseau's challenge 'Return to nature' was popular, and they proposed that the level of economic development should be stopped. By comprehensive approach to the problem we can see that the humanity get civilized society because of social development, particularly, the changes in the human mind and consciousness. The main cause of this phase was the equipment and technology, and there will be neither future nor development without technology. The development of technology will serve for the future of mankind, if we can change instinct for self-protection in the mind of man to the skill of understanding and thinking of personal interests with public interests consciously. So, nowadays we should make conducting propaganda campaigns not among the scientific society, but it will be better if we can achieve wide conducting campaign among the common people. That's why, in the public opinion we have to develop the thoughts about consequences of terrible approach to nature. Because an approach to society will be proved theoretically, when we develop the approach to nature among the scientific society. And when we make conducting propaganda campaigns among the common people, an approach to nature will be proved practically.

Second, we can say with full confidence that it is very difficult to overcome the problems of the $21^{\text {st }}$ century. In many cases, current problem becomes as in evolutionary stage of development, and as a result of it humanity will remain in the problem forever. For example, we can see those problems in the followings: water shortages, food shortages, a violation of the atmosphere, a decay of on-ground and underground resources, an aggravation of population growth, religious fundamentalism associated with social conscience, and of course, the terrorism which going to become combined with geopolitics. According to Aurelio Peccei, Many problems on the way of mankind have already combined tightly with each other. The problems make the world to suffer like a great octopus squeeze the whole Planet with its arms... the number of unresolved problems are increasing, they are becoming more aggravated, their difficultness are getting much more complicated, and our Planet is getting increasingly 'squeezed by the grip' of the problems [9, 7]. Thus, instead of struggling to remove the current problem, it will be much more effective, if we try to prevent it going to the next step. In order to get this aim, it is required to increase the impact of ideological immunity and ideological education in the public mind. So, unless man tries consciously, there will be not result of any event or action.

Third, if humanity continues his rapid developing without taking into account the possibilities of nature and its laws of development, the socio-economic, environmental issues including: the land erosion, loss of forests, too much fish poaching, salty rains, air pollution, in violation of the ozone layer and disasters will increase on the Earth. The consequences of all these will be fatal for human being. That may make the life to die on the planet of Earth the only place to live for man. Nowadays none of us allow and forget such trends which getting manifested as a simple truth. In other words, it is necessary to achieve the unity of the nations of the world and the collective corporation. The only way to achieve such a result is widely developing of the public opinion focused on possible problems.

Fourth, in a word, it is possible to reduce the growth rate of the current problems, and weaken the progress of evolving into new forms as a result of the formation of public opinion against the existing problems.

To achieve such a result, public opinion should be focused on, especially:

- Preventing the shortage problem of oxygen which dear factor for human life;

- Preventing the shortage problem of drinking water which necessary for the survival of every living soul;

- Preventing the improper use of energy, food and natural resources problem which distorting the natural balance of the Earth;

- The most important point is that it is very necessary to develop the ideological immunity against the consequences of the result of Demographic Bang. Because the demographic bang is counted as an object of all global problems. Achieving that aim is required the development of approaching ethics and even the mind of every citizen of the Planet Earth. Because the progress of science and technology is developing at a rapid pace on the threshold of $21^{\text {st }}$ century. Geo-political structure of the world is changing. In this condition the following are become increasingly urgent: the regulation of impact to the biosphere by man; the impact of the preservation of the natural environment with the social development; achieving the balance in interrelations of nature and man [1,101]. Therefore, it is possible to achieve the ultimate stability as a result of developing the public opinion on importance of functional integrating phase between nature and man. 


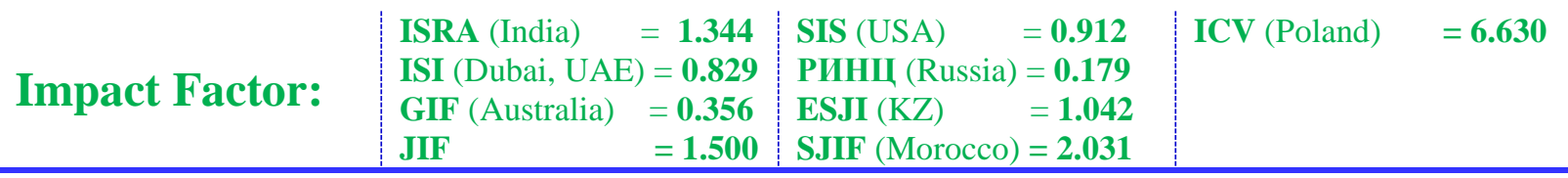

\section{References:}

1. Karimov IA (1998) Havfsizlik va bark'arorlik jy̆lida. T.6. - T.: Y̌zbekiston, 1998. - pp.100.

2. Mamashokirov S (2012) Vah'imami joki h'ak'ik'at. - T.: IK'TISOD-MOLIJa, 2012. pp. 148.

3. (2015) Dretler falsafasi (Amidin Nazarov). Available:

http://www.faylasuf.uz/index.php/falsafa/amali y-falsafa/qadriyatlar (Accessed: 20.09.2015).

4. (2015) Toshkent car-year the Institute "falsafa" kafedrasi. Available: http://www.uz.denemetr.com/docs/769/index31912-1.html?page=12 (Accessed: 20.09.2015).

5. Golubev IR, Novikov JV (1987) Okruzhajushhaja sreda i transport. - Moscow: Transport, 1987. 207 p.

6. Shabanov AH (2012) Ik'lim y̌zgarishi - atrofmuh'it va ah'oli sog'lig'iga ta\#siri. - T.: 2012. pp.3.

7. (2014) Filosofs'ki problemi prirodnichih, tehniko-tehnologichnih i social'no-gumanitarnih disciplin. Zbirnik naukovih statej molodih vchenih. -H.: Mis'kdruk, 2014. -pp.121.

8. Knjazeva EN, Kurdjumov SP (2005) Osnovanija sinergetiki. Sinergeticheskoe Mirovidenie. - Moscow: KomKniga, 2005. pp. 20.

9. Pechchei A (1980) Chelovecheskie kachestva. Moscow: Progress, 1980. - pp.123-124.

10. (2000) «Kruglyj stol» zhurnala «Voprosy filosofii», posvjashhennyj obsuzhdeniju knigi N.N.Moiseyeva «Byt' ili ne byt' ... chelovechestvu?». «Voprosy filosofii». № 9, 2000. - pp. 5-6.

11. Moiseyev NN (2007) Razmyshlenija o budushhem Rossii i mira. // Vestnik Moskovskogo universiteta. Serija 12. Politicheskie nauki. 2007. № 3. - pp. 48. 